\title{
Analysis of Profitability, Liquidity, Dividend Policy, Growth and Asset Structure toward Capital Structure and Firm Value
}

\author{
Ade Elsa Betavia \\ Universitas Negeri Padang, Padang, Indonesia, $\square$ elsabetavia@gmail.com
}

\begin{abstract}
The purpose of this study was to determine the effect of Profitability (ROE), Liquidity (CR), Dividend Policy (DPR), Growth (Sales Growth), Asset Structure of the Capital Structure (DER) and Firm Value (PBV). This population of this study is manufactured industry listed in Indonesia Stock Exchange year 2010-2014. The method used is a quantitative method with the statistical analysis of panel data regression. Using Capital Structure and Firms Value as variable dependent and Profitability, Liquidity, Dividend Policy, Growth, Asset Structure as independent variables. Results of the study showed that partial Probability (ROE) and Liquidity (CR) significant on the Capital Structure (DER). Dividend Policy (DPR), Growth (sales growth) and Asset Structure not influence significantly to the Capital Structure (DER). Probability (ROE) and Capital Structure (DER) significant on the Firm Value (PBV). Liquidity (CR), Dividend Policy (DPR), Growth (sales growth) and Asset Structure not influence significantly to the Firm Value (PBV). Profitability (ROE), Liquidity (CR), Dividend Policy (DPR) , Growth (Sales Growth) and Asset Structure simultaneously significant on the Capital Structure (DER). Profitability (ROE), Liquidity (CR), Dividend Policy (DPR), Growth (Sales Growth), Asset Structure and Capital Structure (DER) simultaneously significant on the Firm Value (PBV).
\end{abstract}

Keywords : profitability (ROE), liquidity (CR), Dividend Policy (DPR), Growth (sales growth), asset structure, capital structure (DER), firm value (PBV)

\section{Introduction}

The company was founded with the aim of prospering the company owners. This goal can be realized by maximizing the value of the firm with the assumption that the owners of the company or shareholders will prosper if their wealth will improve. In achieving this goal, the company must consider all of the company's activity, one of them is a financial management company. Financial management is influenced by financial decisions such as funding or financing decisions. The funding decision is a decision about how much the level use of debt compared to equity investment fund in the company or a decision that aims to determine the optimal capital structure to improve the Firm Value (Sheikh and Wang, 2011).

A company at the beginning of its business with their funding will meet the needs, prioritize for fulfilling of internal resources of the company, thereby reducing reliance on outside parties. Shortly after the business is run, the companies are required to seek alternative funding from other sources, and in this case from outside the company (external sources). The company uses an external source will first choose to use debt, both short term, or long term before issuing shares. This is in accordance with the theory of the Pecking Order that is expressed by Myers and Majluf (1984). Pecking Order Theory (POT) declared that "the determination of the source of the capital's optimal hierarchical funding decisions are based on cost of capital based on the most cost effective from an internal source of funding (earnings) to an external source of funding (debt and shares).

Capital structure is an important element for the company because the good or bad capital structure will directly affect the company's financial position, which will ultimately affect the Firm Value. Capital structure shows the proportion of the use of debt to finance its investments, so by knowing the structure of capital, investors can find out the balance between risk and return on investment. Error in determining capital structure will impact broadly, especially if the company is too big to use debt, so the burden remains to be covered by large companies. It also means increasing 
financial risk, ie. risk when the company can not pay back the interest cost on the loan or the installment of its debt. The capital structure is also expressed as the proportion of funding with corporate debt, the ratio of leverage companies. Thus, debt is an important element of the company's capital structure. Capital structure is the key to improving the productivity and performance of the company.

Because decisions about capital structure so important then an enterprise managers need to consider the factors in determining capital structure so that if the right decision will be able to maximize the Firm Value. For this research there are many factors that will be used as the object of research related to capital structure and the firm value namely profitability, liquidity, dividend policy, the company's growth and structure of assets. Research on capital structure aims to determine the capital structure theories or models that could explain the behavior of the company's funding decisions and will ultimately lead to the low firm value. Although theoretically, the factors affecting the capital structure decisions are hard to measure, but empirical study aims to identify the factors that affect the company's funding decision has been widely performed.

Previous studies conducted have varying results as research conducted by Ogbulu and Emeni (2012) in her research concluded tangibility, growth and profitability do not have a significant impact against the capital structure. The results of this research, in contrast to Sari and Haryanto (2013) stated that the profitability, liquidity, asset growth and has a negative influence to the structure of capital. So also with the research conducted by Wijaya and Utama (2014) stating that the profitability of influencing capital structure and share price while the sales growth does not affect the structure of capital and stock price. In contrast to research done Saleem et all (2013) shows the reverse that effect negatively to the company's growth capital structure. Seftianne and Handayani (2011) States that the structure of the assets has no effect on the structure of capital, while the Wijaya and Utama (2014) stated asset structure has an impact on capital structure. Research related to the dividend policy has also contradictory results. Mulyono (2009) research results indicate that the capital structure has a significant positive influence against the dividend policy. However, in contrast to the results of research and Kusumaningtias (2010) shows that the dividend policy does not affect the capital structure

Research related to the firm value also produces different results among other things, research by Kasumajaya (2011) profitability, growth company and the capital structure influential positive against the firm value. In line with that, the research conducted by the Putra(2014) ROA, ROE and company growth has positive influence against the firm value as well as research Dewi and Wirajaya (2013). In contrast to the study by Anzlina and Rustam (2013), declared partially ROE has no influence with firm value and liquidity (CR) has significant effects against the firm value (MVE). On the other hand, research by Nurhayati (2013) stated that the profitability of a significant and positive relationship with the firm value, the company's liquidity does not have significant influence towards the firm value. Sumanti and Mangantar (2015) results showed that a variable dividend policy has no effect significantly to the firm value. While according to Wijaya (2010) stated dividend policy has a positive influence and significantly to the firm value. While the structure of the asset according to Rusiana (2013) States do not affect the assets structure significantly to the firm value.

Based on the above explanation and the difference of previous research results, the authors are interested in conducting a study entitled "Analysis of Profitability, Liquidity, Dividend Policy, Growth and Asset Structure toward Capital Structure and Firm Value "

\section{Methods}

This research is empirical research that is done by analyzing the data historically, using regression analysis to test for the existence of significant influence between the profitability, liquidity, dividend policy, growth and asset structure against the capital structure and firm value at the manufacturing companies listed on the Indonesia stock exchange at 2010-2014. This research belong to quantitative research. The population in this research is the manufacturing companies listed on the Indonesia 
stock exchange from year 2010-2014 that is as much as 141 companies. This study used a purposive sampling technique. The data used in this research is secondary data.

The variable in this study is divided into the exogenous variables or independent including profitability, liquidity, dividend policy, growth, and asset structure and endogenous variables as well as the dependent variable, the of capital structure and firm value.

\section{Data analysis techniques}

\section{Descriptive Statistics Analysis}

Statistics descriptions provide information about the data that will be tested in the research and give you an idea about something the data views from the mean, standard deviation, minimum, maximum, tables and more.

\section{The Selection Panel Regression Model}

Widarjono (2007:231) suggests that there are three methods used for regression models of estimate data panel as follows:

1. Coefficient remains Between the time and the individual (common effect or pooles least squere).

2. Slope Constant But Intercept Different between individuals (fixed effects).

3. Estimation Approach With Random Effects.

Two techniques of estimating the data panel regression model above to select the most appropriate to estimate panel data regression. Three tests are used, the first test Chow or F restricted to choose between the common effect or fixed effect. Second, Hausman's test to choose between fixed effect or random effect to estimate regression of data panel. And the LM test is now to choose between PLS and RE.

\section{Classic Assumption Test.}

With this test it is expected that the panel data regression model obtained can be accountable and not biased then the basic assumptions must be met the test of Multicollinearity, Heteroskedastisitas Test, Auto-correlation Test.

\section{Test the hypothesis}

A test of the hypothesis Test is performed with a determinant. T-test and F-test

\section{Result and Discussion}

The Selection Panel Data Regression

To the first equation from the panel data have been collected, these data be regulated using the smallest squares model were collected, the results of which can be seen in Table 1. As for the results of the regression model with fixed effects can be seen in table 2 .

Table 1 Results of regression of capital structure with ROE, CR, DPR, SG and SA using Pooled Least Square (PLS)

$$
\begin{array}{ll}
\text { Namber of obs }= & 300 \\
\mathrm{~F}(5,294) & =18,65 \\
\text { Prob }>\text { F } & =0,00 \\
\text { R-squared } & =0,24
\end{array}
$$

\begin{tabular}{lrrrrrr}
\hline DER & \multicolumn{1}{l}{ Coef } & \multicolumn{1}{l}{ Std.Err } & T & \multicolumn{2}{c}{ P> $|\mathbf{t}|$} & \multicolumn{2}{c}{ (95\% Coef. Internal) } \\
\hline ROE & $-3,113$ & 0,406 & $-7,67$ & 0,000 & $-3,192$ & $-2,314$ \\
\hline CR & $-0,334$ & 0,702 & $-4,74$ & 0,000 & $-0,473$ & $-0,196$ \\
\hline DPR & 0,532 & 0,492 & 1,08 & 0,281 & $-0,437$ & 1,502 \\
\hline SG & 0,607 & 0,282 & 2,15 & 0,033 & 0,050 & 1,163 \\
\hline SA & $-1,453$ & 0,63 & $-2,31$ & 0,022 & $-2,693$ & $-0,212$ \\
\hline Cons & 2,846 & 0,335 & 8,47 & 0,000 & 2,185 & 3,508 \\
\hline
\end{tabular}


Table 2 Results of regression of capital structure with ROE, CR, DPR, SG and SA by using Fixed Effect (FE)

$$
\begin{aligned}
\text { R-sq : within } & =0,3945 \\
\text { between } & =0,0120 \\
\text { overall } & =0,0932
\end{aligned}
$$

$\begin{array}{ll}\text { Number of obs } & =300 \\ \mathrm{~F}(5,235) & =30,63 \\ \text { Prob }>\text { F } & =0,0000\end{array}$

\begin{tabular}{lrrrrrr}
\hline DER & Coef & Std.Err & T & \multicolumn{1}{c}{ P $>|\mathbf{t}|$} & \multicolumn{2}{c}{ (95\% Coef. Internal) } \\
\hline ROE & $-3,683$ & 0,406 & $-7,67$ & 0,000 & $-3,192$ & $-2,314$ \\
\hline CR & $-0,098$ & 0,702 & $-4,74$ & 0,000 & $-0,473$ & $-0,196$ \\
\hline DPR & $-1,34$ & 0,492 & 1,08 & 0,281 & $-0,437$ & 1,502 \\
\hline SG & 0,685 & 0,282 & 2,15 & 0,033 & 0,050 & 1,163 \\
\hline SA & $-9,037$ & 0,63 & $-2,31$ & 0,022 & $-2,693$ & $-0,212$ \\
\hline Cons & 5,388 & 0,335 & 8,47 & 0,000 & 2,185 & 3,508 \\
\hline sigma_u & 2,269 & \multicolumn{7}{c}{ Prob $>\mathrm{F}=0,0000$} \\
\hline sigma_e & 1,539 & (fraction of variance due to u_i) & & \\
\hline Rho & 0,684 & $\mathrm{~F}(59,235)=4,72$ &
\end{tabular}

Data source: Data Results STATA 12

After the results of the model least square pool and fixed-effects retrieved then done F restricted or Chow tests. Tests necessary to choose the most suitable model between the square and the effect pool model of fixed effects. In this test you want to view is prob F value where if the value is smaller than the alpha then Ho will be denied where on this test: H0 and H1: PLS FE. From the table above shows that the prob F 0.0000 and smaller than 0.05 so that alpha value of $\mathrm{F}$ is limited it was decided that $\mathrm{H} 0$ is rejected so that the model used was the model of fixed effects. Next we will do a random effects model with regression, regression models to determine the right panel. The regression results using random effects models can be seen in table 3 .

Table 3 Results of regression of capital structure with ROE, CR, DPR, SG and SA by using Random Effect (RE)

$$
\begin{aligned}
& \text { R-sq: within }=0,3462 \\
& \text { Number of obs }=300 \\
& \text { between }=0,1076 \\
& \text { Wald chi2 (5) } \quad=120,51 \\
& \text { overall }=0,2132 \\
& \text { Prob }>\text { chi2 } \\
& =0,0000
\end{aligned}
$$

\begin{tabular}{lcccccr}
\hline \multicolumn{1}{c}{ DER } & Coef & Std.Err & \multicolumn{1}{c}{ Z } & P > $|\mathbf{z}|$ & \multicolumn{2}{c}{ (95\% Coef. Internal) } \\
\hline ROE & $-3,523$ & 0,373 & $-9,43$ & 0,000 & $-4,254$ & $-2,791$ \\
\hline CR & $-0,224$ & 0,862 & $-2,60$ & 0,000 & $-0,393$ & 0,055 \\
\hline DPR & $-0,307$ & 0,554 & $-0,55$ & 0,580 & -1.394 & 0,779 \\
\hline SG & 0,728 & 0,241 & 3,02 & 0,002 & 0,256 & 1,201 \\
\hline SA & $-2,905$ & 0,899 & $-3,23$ & 0,001 & $-4,669$ & $-1,141$ \\
\hline Cons & 3,320 & 0,454 & 7,31 & 0,000 & 2,429 & 4,210 \\
\hline sigma_u & 1,210 & \multicolumn{7}{c}{} \\
\hline sigma_e & 1,539 & & & & \\
\hline Rho & 0,381 & (fraction of variance due to $u_{-} i$ ) & \\
\hline
\end{tabular}

Data source: Data Results STATA 12

After the above stages, has not been able to determine which model will be used. Therefore, it is necessary to search for Hausman tests specify one. In table 4 Hausman test results has been performed using Stata 12. Hausman Tests in the H0: RE while FE is H1 with criteria if the value of P 
(Prob > Chi2) 0.05 then H1 alpha < received or it means the best option is FE than RE. Hausman test results can be seen in the table below:

Table 4 Result Hausman Test Fe, Re regression Capital Structure

\begin{tabular}{|c|c|c|c|c|}
\hline & $\begin{array}{l}\text { (b) } \\
\text { fe }\end{array}$ & $\begin{array}{l}\text { (B) } \\
\operatorname{Re}\end{array}$ & $\begin{array}{c}b-B \\
\text { difference }\end{array}$ & $\begin{array}{c}\operatorname{sqrt}\left(\operatorname{diag}\left(V_{-} b-V_{-} B\right)\right. \\
\text { S.E. }\end{array}$ \\
\hline ROE & $-3,683$ & $-3,523$ & $-0,16$ & 0,134 \\
\hline CR & $-0,098$ & $-0,244$ & 0,125 & 0,071 \\
\hline DPR & $-1,34$ & & $-1,032$ & 0,432 \\
\hline SG & 0,685 & 0,728 & $-0,432$ & . \\
\hline SA & $-9,03777$ & $-2,905$ & $-6,132$ & 1,443 \\
\hline & & & & Chi2 (5) \\
\hline
\end{tabular}

From the table above shows that the Prob > chi2 is 0.0000, smaller than 0.05 Alpha so it was decided that $\mathrm{HO}$ is rejected and the $\mathrm{H} 1$ is accepted. With these results it is clear that the model used for the data panel is Fixed Effects (FE). After the first equation, the influence of ROE, CR, DPR, SG, SA on the capital structure obtained the best regression model then for the equation of both the influence of ROE, CR, DPR, SG, SA, DER against company value (PBV) also will be done step above choose the best model. Table 5 is PLS and table 6 is FE

Table 5 Results of regression of firm value with ROE, CR, DPR, SG and SA by using Pooled Least Square (PLS)

$$
\begin{array}{ll}
\text { Namber of obs }= & 300 \\
\mathrm{~F}(6,293) & =25,46 \\
\text { Prob }>F & =0,000 \\
\text { R-squared } & =0,342
\end{array}
$$

\begin{tabular}{lrrrrrr}
\hline PBV & \multicolumn{1}{l}{ Coef } & \multicolumn{1}{l}{ Std.Err } & \multicolumn{1}{c}{ T } & \multicolumn{1}{l}{$\mathbf{P}>|\mathbf{t}|$} & \multicolumn{2}{c}{ (95\% Coef. Internal) } \\
\hline ROE & 5,860 & 1,033 & 5,67 & 0,000 & 3,826 & 7,894 \\
\hline CR & $-0,140$ & 0,169 & $-0,83$ & 0,409 & $-0,473$ & 0,193 \\
\hline DPR & 8,820 & 1,147 & 7,69 & 0,000 & 6,591 & 11,078 \\
\hline SG & $-0,015$ & 0,662 & $-0,02$ & 0,982 & $-1,318$ & 1,288 \\
\hline SA & 1,887 & 1,477 & 1,28 & 0,202 & -1.020 & 4,796 \\
\hline DER & 0,659 & 0,135 & 4,87 & 0,000 & 0,393 & 0,926 \\
\hline Cons & $-1,042$ & 0,870 & $-1,20$ & 0,232 & $-2,755$ & 0,671 \\
\hline
\end{tabular}

Table 6 Results of regression of firm value with ROE, CR, DPR, SG and SA by using Fixed Effect (FE)

$\begin{array}{rlll}\text { R-sq : within } & =0,1863 & \text { Number of obs } & =300 \\ \text { between } & =0,0100 & \mathrm{~F}(6,234) & =8,93 \\ \text { overall } & =0,0193 & \text { Prob }>F & =0,0000\end{array}$

\begin{tabular}{lrrrrrr}
\hline \multicolumn{1}{c}{ PBV } & Coef & Std.Err & \multicolumn{1}{c}{ T } & P> $|\mathbf{t}|$ & \multicolumn{2}{c}{ (95\% Coef. Internal) } \\
\hline ROE & 0,493 & 0,407 & 1,21 & 0,227 & $-0,309$ & 1,296 \\
\hline CR & $-0,086$ & 0,098 & $-0,88$ & 0,378 & $-0,280$ & 0,106 \\
\hline DPR & $-0,041$ & 0,622 & $-0,07$ & 0,947 & $-1,267$ & 1,184 \\
\hline SG & 0,371 & 0,211 & 1,76 & 0,080 & $-0,044$ & 0,787 \\
\hline
\end{tabular}


Table Cont...

\begin{tabular}{lrlllll}
\hline SA & $-1,999$ & 1,580 & $-1,26$ & 0,207 & $-5,114$ & 1,115 \\
DER & 0,297 & 0,057 & 5,20 & 0,000 & 0.184 & 0,410 \\
\hline Cons & 3,270 & 0,670 & 4,88 & 0,000 & 1,950 & 4,590 \\
\hline sigma_u & 5,267 & & & & \\
\hline sigma_e & 1,352 & & & & \\
\hline Rho & 0,954 & (fraction of variance due to $u \_i$ ) & & \\
\hline
\end{tabular}

the result of pool least square model and fixed effect is obtained then F Restricted or Chow Test. The test is required to select the most appropriate model among the least square and fixed effect pool models. In this test which will be seen is prob F value where if the value is small from alpha then Ho will be rejected where in this test H0: PLS and H1: FE. From the table above shows that the prob F of 0.0000 and small from the alpha value of 0.05 so that from F Restricted or Chow Test it was decided that $\mathrm{HO}$ is rejected so that the model used is the fixed effect model. Next we will do regression with random effect model, to determine the right panel regression model. The result of regression using random effect model can be seen in table 7 .

Table 7 Results of regression of firm value with ROE, CR, DPR, SG and SA by using Random Effect (RE)

$\begin{array}{clcc}\text { R-sq : within } & =0,1772 & \text { Number of obs } & =300 \\ \text { between } & =0,1304 & \text { Wald chi2 }(6) & =51,77 \\ \text { overall } & =0,1061 & \text { Prob }>\text { chi } 2 & =0,0000\end{array}$

\begin{tabular}{lrrrrrr}
\hline \multicolumn{1}{c}{ PBV } & Coef & Std.Err & \multicolumn{1}{c}{$\mathbf{Z}$} & $\mathbf{P}>|\mathbf{z}|$ & \multicolumn{2}{c}{ (95\% Coef. Internal) } \\
\hline ROE & 0,897 & 0,423 & 2,12 & 0,034 & 0,068 & 1,726 \\
\hline CR & $-0,082$ & 0,100 & $-0,82$ & 0,412 & $-0,279$ & 0,114 \\
\hline DPR & 0,832 & 0,634 & 1,31 & 0,189 & $-0,410$ & 2,075 \\
\hline SG & 0,332 & 0,211 & 1,50 & 0,134 & $-0,102$ & 0,767 \\
\hline SA & $-1,449$ & 1,487 & $-0,97$ & 0,330 & $-4,364$ & 1,465 \\
DER & 0,335 & 0,059 & 5,67 & 0,000 & 0.219 & 0,450 \\
\hline Cons & 2,784 & 0,882 & 3,15 & 0,002 & 1,054 & 4,514 \\
\hline sigma_u & 4,406 & & & & \\
sigma_e & 1,352 & & & & & \\
Rho & 0,913 & (fraction of variance due to $\left.u \_i\right)$ & &
\end{tabular}

The result of regression using fixed effect model can be seen in table 6 and the result of regression using random effect model can be seen in table 7 , all show the result of independent variable has significant effect to dependent that is company value. But we cannot determine which model we will use. Therefore, Hausman test is needed to find out. In table 8 the results of the Hausman test have been performed using Stata 12. In Hausman Test H0: RE while FE is H1 with criteria if P value (Prob> Chi2) <alpha 0,05 then H1 is accepted or which means the best choice is FE of RE.

Table 8

The results of Hausman Test FE, RE regression of firm value

\begin{tabular}{lllcc}
\hline & (b) & (B) & \multicolumn{1}{c}{$\boldsymbol{b}$-B } & sqrt $\left(\operatorname{diag}\left(V_{-} \boldsymbol{b}-V_{-} \boldsymbol{B}\right)\right)$ \\
& Fe & re & Difference & S.E. \\
\hline ROE & 0,493 & $-0,897$ & $-0,403$ & \\
\hline CR & $-0,086$ & $-0,082$ & $-0,004$ & . \\
\hline DPR & $-0,413$ & 0,832 & $-0,874$ & \\
\hline
\end{tabular}


Table Cont...

\begin{tabular}{lrrrrr}
\hline SG & 0,371 & 0,332 & 0,390 & 0,536 \\
\hline SA & $-1,999$ & $-1,449$ & $-0,550$ & \\
DER & 0,297 & 0,335 & $-0,037$ &. \\
\hline & & \multicolumn{5}{c}{ Chi2 (6) } & $=-102,25$ & \\
& & & chi2<0 &
\end{tabular}

Data source: Data Results STATA 12

From Hausman test results obtained above, it was decided that the model used is the Random Effect model. Next will be done Then will the LM test where the test aims to select the regression model to be used between PLS and RE.

The Result of Breusch and Pagan Lagrangian multipier test for random effects:

chibar2 (01) $=382,47$

Prob $>$ chibar2 $=0,000$

With the Breusch and Pagan Lagrangian multipier tests for random effects, it was decided that the best regression model used in the equation to see the effect of ROE, CR, DPR, SG, SA and DER on PBV is a random effect.

\section{Classic assumption test}

After determining the panel data regression model to be used, then the next step is to test and meet the assumptions needed to test the data panel. The tests required are multicollinearity, heteroscedasticity, and autocorrelation tests.

\section{Multicollinearity Test}

The first assumption we tested is the absence of multicollinearity. Multicollinearity is the relationship between independent variables. To detect multicollinearity, we see by looking at tolerance values (1 / VIF) and variance inflation factor (VIF). In this study, the first two regression models of the regression model to see the effect of ROE, CR, DPR, SG and SA on capital structure (DER). Results multicollinearity can be seen in table 9 below:

Table 9 Multicollinearity Test Results for the first equation

\begin{tabular}{lcr}
\multicolumn{1}{c}{ Variabel } & VIF & \multicolumn{1}{c}{ 1/VIF } \\
\hline ROE & 1,45 & 0,698 \\
\hline CR & 1,77 & 0,563 \\
\hline DPR & 1,96 & 0,509 \\
\hline SG & 1,11 & 0,903 \\
\hline SA & 1,73 & 0,578 \\
\hline
\end{tabular}

From the test results show that there is no multicollinearity among the independent variables in the first regression model. Similarly, with the second equation, the influence of ROE, CR, DPR, SG, $\mathrm{SA}$ and DER against firm value is also no problem multicollinearities.

Table 10 Multicollinearity Test Results for the second equation

\begin{tabular}{lcr}
\hline \multicolumn{1}{c}{ Variable } & \multicolumn{1}{c}{ VIF } & \multicolumn{1}{c}{ 1/VIF } \\
\hline ROE & 1,62 & 0,618 \\
\hline CR & 1,78 & 0,563 \\
\hline DPR & 1,99 & 0,503 \\
\hline SG & 1,16 & 0,859 \\
\hline SA & 1,96 & 0,511 \\
\hline DER & 1,42 & 0,703 \\
\hline
\end{tabular}




\section{Heteroscedasticity Test}

The second assumption is the absence of Heteroscedasticity. Heteroscedasticity is a variant of the variable disorder that is not constant. The heteroscedasticity test for the usable data panels is the Wald Test. The following Wald test results for heteroscedasticity in panel data on the first equation:

The Results of the heteroscedasticity test for the first equation:

chi2 $(60)=1.5 \mathrm{e}+06$

Prob $>$ chi $2=0,0000$

Following hypothesis on Wald test for heteroscedasticity in panel data:

$\mathrm{H} 0$ : No heteroscedasticity

H1: There is heteroscedasticity

Based on the results of tests with Stata 12, it turns out that the probability of Wald's test data panel is smaller than 0.05 which indicates reject $\mathrm{H} 0$ which states there are still heteroscedasticity problems. For the second equation is the equation that the Random Effect regression model then to see the problem of heteroskedasticities can be seen at the value of Prob F in the table 7 its 0.0000 so this value is smaller than alpha is 0,05 . So, it can be concluded that this equation there is a problem of heteroskedasticities.

\section{Autocorrelation Test}

The autocorrelation test for commonly used panel data is Wooldridge test. The results of this test can be seen from the table below:

The Autocorrelation test results for the first equation:

chi2 (60) $=1.5 \mathrm{e}+06$

Prob $>$ chi $2=0,0000$

Wooldridge test detects autocorrelation based on test result with Stata 12, it turns out probability of test data smaller than 0.05 indicates reject $\mathrm{H} 0$ and accepts $\mathrm{H} 1$ or the selected model has autocorrelation. Likewise, with the second equation there is also the problem of autocorrelation because visible value Prob <alfa $(0,05)$.

Based on the results of heteroscedasticity test and autocorrelation test, the model used has heteroscedasticity and autocorrelation problems. Therefore, in order for the model to be blue, it must be modified first. In the state, we can make other modifications using the Panel-Corrected Standard Error approach, which will solve the problem of heteroscedasticity and autocorrelation. For the first equation, the influence of ROE, CR DPR, SG and SA against DER with the following model can overcome the problem of heteroscedasticity and autocorrelation, in table 11 bellow. For the influence of ROE, CR, DPR, SG, SA and DER on-company value (PBV) decide Random Effect regression model as the best model so that this model does not need to overcome blue problem because using General Method Least Squere (GLS). So, for the regression model used fixed that can be seen in table 7 .

Table 11 Estimation Results with Panel-Corrected Standard Errors Approach

Namber of obs $=300$
$\begin{array}{ll}\text { R- squared } & =0,2228 \\ \text { Prob }>\text { chi } 2 & =0,0001\end{array}$

\begin{tabular}{lcrrrrr}
\hline & \multicolumn{6}{c}{ Panel - corrected } \\
\cline { 2 - 7 } \multicolumn{1}{c}{ DER } & Coef & Std.Err & $\mathbf{z}$ & $\mathbf{P}>|\mathbf{z}|$ & \multicolumn{2}{c}{ (95\% Coef. Internal) } \\
\hline ROE & $-2,722$ & 0,925 & $-2,94$ & 0,003 & $-4,536$ & $-0,908$ \\
\hline CR & $-0,220$ & 0,734 & $-3,00$ & 0,003 & $-0,364$ & $-0,763$ \\
\hline DPR & $-0,662$ & 0,544 & $-1,22$ & 0,223 & $-1,729$ & 0,403 \\
\hline SG & 0,546 & 0,552 & 0,99 & 0,323 & $-0,536$ & 1,629 \\
\hline SA & $-2,661$ & 1,768 & $-1,50$ & 0,132 & $-6,128$ & 0,805 \\
\hline Cons & 3,176 & 0,633 & 5,01 & 0,000 & 1,934 & 4,417 \\
\hline Rho & 0,646 & & & & & \\
\hline
\end{tabular}




\section{The Test of Hypothesis}

\section{Determination of Coefficients Test (Adjusted R ${ }^{2}$ )}

The result of the determination coefficient can be seen in table 11. The figures obtained from the tables $R$ Square $\left(R^{2}\right)$ from 2010 to 2014 is 0.2228 or $22.28 \%$. This shows that the independent variable (ROE, CR, DPR, SG, and SA) can explain the dependent variable (capital structure/DER) of 22.28\%. As for the variable the value of the company (PBV) results determination coefficient can be seen in table 7 , obtained numbers R Square $\left(\mathrm{R}^{2}\right)$ from 2010 to 2014 is 0.1772 or $17.72 \%$. This shows that the independent variable (ROE, CR, DPR, SG, SA and DER) can explain the dependent variable (the value of the company/PBV) of $17.72 \%$. While the rest is affected by other variables that are not included in this research model.

\section{Test $\mathbf{t}$ (Partial)}

$\mathrm{T}$ test results can be viewed in Table 12.

Table 12 Partial Test Results

\begin{tabular}{|c|c|c|c|c|}
\hline Variable & Coef & $P>|z|$ & Results & Description \\
\hline $\mathrm{ROE}$ & $\begin{array}{l}- \\
2,722\end{array}$ & 0,003 & H0 denied & $\begin{array}{l}\text { Profitability have significant effect to capital } \\
\text { structure }\end{array}$ \\
\hline CR & 0,220 & 0,003 & H0 denied & $\begin{array}{l}\text { Liquidity has significant influence to capital } \\
\text { structure }\end{array}$ \\
\hline DPR & $\begin{array}{l}- \\
0,662\end{array}$ & 0,223 & H0 accepted & $\begin{array}{l}\text { Dividend Policy has no significant effect on } \\
\text { capital structure }\end{array}$ \\
\hline SG & 0,546 & 0,323 & H0 accepted & $\begin{array}{l}\text { The growth of the company has no significant } \\
\text { effect on capital structure }\end{array}$ \\
\hline SA & 2,661 & 0,132 & H0 accepted & $\begin{array}{l}\text { Asset structure has no significant effect on } \\
\text { capital structure }\end{array}$ \\
\hline $\mathrm{ROE}$ & 0,897 & 0,034 & H0 denied & $\begin{array}{l}\text { Profitability have significant effect to the firm } \\
\text { value }\end{array}$ \\
\hline CR & $\begin{array}{l}- \\
0,824\end{array}$ & 0,412 & H0 accepted & $\begin{array}{l}\text { Liquidity do not affect significantly to the firm } \\
\text { value }\end{array}$ \\
\hline DPR & 0,832 & 0,189 & H0 accepted & $\begin{array}{l}\text { Dividend policy does not have significant } \\
\text { influence towards the firm value }\end{array}$ \\
\hline SG & 0,332 & 0,134 & H0 accepted & $\begin{array}{l}\text { The growth of the company has no significant } \\
\text { effect on the firm value }\end{array}$ \\
\hline SA & $\begin{array}{l}- \\
1,449\end{array}$ & 0,330 & H0 accepted & $\begin{array}{l}\text { Asset structure of the company has no } \\
\text { significant effect on the firm value }\end{array}$ \\
\hline DER & 0,335 & 0,000 & H0 denied & $\begin{array}{l}\text { Capital structure influential significantly to the } \\
\text { firm value }\end{array}$ \\
\hline
\end{tabular}

\section{F Test (simultaneously)}

\section{Twelve Test Hypothesis (H12)}

Look at Table 12 found that the value of 0.0001 probability of significant value of 0.05 . So H0 is rejected and so the $\mathrm{Ha}$ is received. It can be said that the simultaneous profitability, liquidity, dividend policy, growth and asset structure have significant influence towards the capital structure.

Test The Hypothesis Thirteenth (H13)

In table 8, Random-effects regression models found that the value of the probability of 0.00000 smaller than 0.05 so that $\mathrm{H} 1$ is accepted. It can be stated that simultaneously or concurrently the profitability, liquidity, dividend policy, growth, asset structure and capital structure has significant effects against the firm value. 


\section{Conclusion}

This study aims to present empirical evidence on the influence of profitability (ROE), liquidity (CR), dividend policy (DPR), growth (SG), asset structure (SA) to capital structure (DER) and firm value (PBV) manufacturing listed on the Indonesia Stock Exchange (BEI) in 2010-2014. The conclusion of data analysis result can be seen as follows:

1. From result of determination coefficient test $\left(R^{2}\right)$ found that independent variable (ROE, $C R$, DPR, SG and SA) can explain dependent variable (capital structure / DER) equal to 22,28\%. And independent variables (ROE, CR, DPR, SG, SA and DER) can explain the dependent variable (firm value / PBV) of $17.72 \%$.

2. Partially can be concluded that profitability (ROE) and liquidity (CR) have significant effect to capital structure (DER). While dividend policy variable (DPR), growth (SG) and asset structure (SA) have no significant effect to capital structure (DER).From $t$ test also found that profitability (ROE) and capital structure (DER) have significant effect to firm value (PBV). But for liquidity (CR), dividend policy (DPR), corporate growth (SG) and asset structure (SA) have no significant effect on firm value (PBV).

3. Along with the F test, it was found that jointly ROE, liquidity (CR), dividend policy (DPR), corporate growth (SG) and asset structure (SA) had a significant effect on capital structure (DER) manufacturing registered in Indonesia. Stock Exchange (BEI) in 2010-2014. And it can be stated that simultaneously profitability (ROE), liquidity (CR), dividend policy (DPR), corporate growth (SG), asset structure (SA) and capital structure (DER) have significant effect on firm value (PBV).

\section{References}

Anzlina,Corry Winda dan Rustam. (2013). Influence of Liquidity Level, Solvability, Activity and Profitability to Company Value on Real Estate and Property Company. Journal of Economists, Vol 16, No 2, April 2013

Dewi, Ayu S.M dan Wirajaya, Ary. (2013). The Influence of Capital Structure, Profitability and Company Size on Corporate Value. E-Journal of Accounting.Udayana University 4.2 p: 358-372

Kusumajaya, Dewa Kadek Oka. (2011). Influence of Capital Structure and Corporate Growth on Profitability and Value of Company in Manufacturing Company in Indonesia Stock Exchange. Thesis. Postgraduate of Universitas Udayana.

Myers, Stewart C., and Nicholas S Majluf. (1984). Corporate Financing and Investment Decisions When Firmz Have Information That Investors Do Not Have. Journal of Financial Economics, (13), pp: $187-221$

Mulyono, Budi, (2009). The Influence of Debt to Equity Ratio, Insider Ownership, Size, and Investment Opportunity Set to the Dividend Policy (Study on Manufacturing Industry Listed in Indonesia Stock Exchange Period Year 2005-2007) ", Thesis, Universitas Dipenogoro, Semarang.

Nurhayati, Mafizatun. 2013. Profitability, Liquidity and Company Size Influence on Dividend Policy and Corporate Value Non service sector. Journal of Finance and Business Vol. 5, No. 2, July 2013.

Ogbulu, O., \& Emeni, F. 2012. Capital Structure and Firm Value: Empirical Evidence from Nigeria. International Journal of Business and Social Science, 252-261.

Putra, Nyoman Wedana Adi. 2014. The Influence of Fundamental Factors On The Value Of Telecommunication Sector Companies In Indonesia Stock Exchange. E-Journal of Accounting Universitas Udayana. 8.3, p: 385-407

Puspita Gita Cahya dan Kusumaningtias Rohmawati. 2010. Influence of Asset Structure, Profitability, and Dividend Policy on Capital Structure of Banks Listed on IDX In 2005-2009 "acrual journal (journal of accounting) vol. 2 october 1, 2010 / page 70-84 / issn 2085-9643

Rusiana,Ime Ernate 2013. The Effect of Asset Structure, Investment Returns, ROE, Size and BVES on Corporate Value Listed in (2008-2011) with PBV Measurement Tool. Scientific Journal of Universitas Dian Nuswantoro Semarang. 
Sari, Devi Verena dan Haryanto,Mulyo.A. 2013. Effect of Profitability, Asset Growth, Company Size, Asset Structure and Liquidity to Capital Structure. Diponegoro Journal Bisnis and Management. Vol 2 No 3 hal 1.

Saleem, Faiza., Bisma Rafique, Qaiser Mehmood, Muhammad Irfan, Rabia Saleem, Sidra Tariq, and Ghazala Akram. 2013. The Determinants of Capital Structure of Oil and Gas Firms Listed on Karachi stock Exchange In Pakistan. Interdisciplinary Journal

Seftianne dan Ratih Handayani. 2011. Analysis of Factors Affecting the Capital Structure of a Public Company The manufacturing sector. Journal of Business and Accounting. Vol.13, No.1, April 2011. Pp: 39-56.

Sheikh, Nadeem Ahmed and Zongjun Wang, 2011. "Determinants of Capital Structure An Empirical Study of Firms in Manufacturing Industry of Pakistan", Journal Managerial Finance, Volume 37 pp $117-133$

Sumanti Jorenza Chiquita dan Marjam Mangantar.2015. Analysis of managerial ownership of debt policy and profitability against dividend policy and corporate value. at a manufacturing company listed on the IDX. EMBA Journal Vol.3 No.1 March 2015, P.1141-1151

Widarjono, Agus. 2007. Econometrics Theory and Applications. Yogyakarta: Econisia FE UII.

Wijaya, I Putu A.S dan Utama, I Made.K. 2014. Effect of Profitability, Asset Structure and Sales Growth Against Capital Structure And Stock Price. E-Journal of Accounting Udayana University 6.3 (2014): 514-530

Wijaya, L.R.P, Wibawa, A. 2010. Influence of Investment Decision, Fund Decision, And Dividend Policy To Company Value. National Symposium on Accounting XIII Purwokerto. 